\title{
Prevalence Causes of Stress and Coping Strategies Among Malaysian University Lecturers
}

\author{
Khairunesa Isa ${ }^{1} \&$ Sarala Thulasi Palpanadan ${ }^{2}$ \\ ${ }^{1}$ Department of Social Science, Universiti Tun Hussein Onn Malaysia, 86400, Parit Raja, Batu pahat, Johor, Malaysia \\ ${ }^{2}$ Department of English Language and Linguistics, Universiti Tun Hussein Onn Malaysia, 86400, Parit Raja, Batu \\ pahat, Johor, Malaysia \\ Correspondence: Khairunesa Isa, Department of Social Science, Universiti Tun Hussein Onn Malaysia, 86400, Parit \\ Raja, Batu pahat, Johor, Malausia.
}

Received: July 11, 2020

Accepted: August 10, 2020

Online Published: August 11, 2020

doi:10.5430/ijhe.v9n5p312

URL: https://doi.org/10.5430/ijhe.v9n5p312

\begin{abstract}
As an academician, lecturers are tied to job scope that are related to teaching and learning, research, publication, consultancy, and community services. All these tasks have occasional loads and excessive load may cause stress to lecturers. This study was conducted to identify the level of Malaysian lecturers' stress and the major prevalence causes of stress among them. In addition, the relationship between stressor factors to the lecturers' stress was tested as well. This research used a survey technique. A questionnaire with four Likert Scale was used as an instrument for data collection. The instrument comprised three sections with 33 items. A total of 609 respondents were randomly selected from four Malaysian Public Universities as respondents. The data were analyzed descriptively and inferentially using SPSS 24.0. The findings showed that Malaysian lecturers experienced stress at low levels. Three main factors which included the university factor, social factor and individual factor had significant relationships to lecturers' stress. In addition, work load, work environment, networking, health, and financial factors also were seen as major prevalences that contributed to the lecturers' stress issue.
\end{abstract}

Keywords: health and personal, lecturer, prevelance factor, stress, work load

\section{Introduction}

Globalization and revolution in the industry demand the country to make transformation in the education system in order to produce human resources in line with future needs and requirements. Subsequently, academic achievements as well as the education system need to ensure a more competitive workforce, superiority and resilient personality to face the challenges of the future. Thus, the country will be able to produce human resources who are capable of fulfilling the work market at local and global levels.

\subsection{Problem Statement}

Academicians are important resources in teaching and learning systems. At higher education level such as universities, colleges and other academic institutions or skill centers, the academicians or lecturers have the main responsibility to ensure that students are ready to meet the work market needs. In this aspect, the lecturers will ensure that students have a high level of competency besides having good soft skills. In addition to teaching and learning, academics are also tied to the need for writing, publication, research and community services. The lecturers should also be the role models to students by demonstrating good examples as all the conducts of lecturers always draw the students' attentions.

There are many more job scopes to enhance the lecturers' career development such as attending courses that are available to add knowledge and involving in other general aspects such as following the laws that have been set by the university and the government. Even though each area has a different weight, it still demands academicians to provide high commitment in each field especially in terms of time management and output quality produced. All these responsibilities can cause stress to the lecturers and stress can cause the tension in psychology, physiology and behavior (Deepti and Hemant, 2018).

Stress is a conflict that is experienced in a person. Stress in the organization occurs when the work needed do not match with the ability, resources and needs of employees. Organizational workers with stress are going to have a change in behavior, adverse effects on the health aspects of self and organization productivity (Okeke et al., 2016). Prolonged 
stress will affect the physical aspect of the individual depending on the individual's reaction in facing the stress. Sweeny et al. (2020) states that individuals who are in the crisis will build stress when they continue to worry about this situation and ultimately can cause the individual to lose focus in life. The individuals who are able to be resilient with stress can develop cardiovascular disease (heart) and musculoskeletal disorder (disorder of the nervous system, joints, ligament, muscles and tendons) in the long run. The employment of the disease of musculoskeletal jobs from 1995 until 2009 showed a substantial increase from 77 cases in 2008 to 161 cases in 2009.

The AIA Insurance company website in 2018 listed the effects of stress that will be experienced by individuals if stress is not managed well such as insomnia, difficult to focus and forget, headache, cardiovascular disease, and interrupted digestive system and emotion. The effects of direct stress will disrupt the body's system and affect the thought and behaviour of individuals. This effect further contributes to other negative effects such as the level of employee acceptance of the work done, low self-confidence, the presence of a duty, sleeping on the job and the most dreaded, being burn out. Symptoms of burn out among workers vary but they include all or some of the following: absenteeism from work, depression, eating disorders, pains where the sources cannot be located, fainting, impatience, headaches, and lack of concentration (Fowler, 2018). On a similar note, Ormrod (2013) argued that research evidence indicated that work-life stress serves as a negative occupational exposure relating to poor health behaviors, including smoking, poor food choices, low levels of exercise, and decreased sleep time.

According to Bianchi et al. (2019), individuals can experience burn out if stress occurs continuously that ultimately causes individuals to have strong immune forces. Stress also caused workers to make mistakes and become negligent while performing a task that ultimately leads to accidents, low product quality and adversely affect the overall work system and organizational performance (Hoel et al., 2020). Thus, this study was conducted to identify the level of Malaysian lecturers' stress including the major prevalence causes of the stress. In addition, the relationship between stressor factors and the lecturer's stress was tested as well.

\section{Stress among Lecturer}

According to Rahim \& Yatim (2017), there are a number of other factors that could affect the emotional level of academics and non-academics, where it affects the psychological and physical aspects of employees such as not being recognized for achievements performed, salary rates that are not in line with the workload of duties given by the employers. Due to that, Lyubomirsky et al. (2005) and Pressman \& Cohen (2005) felt that the employees of the organization were unhappy while performing their duties as individuals with depression, mental illness, inferiority complex and defiance of socializing activities.

Parent-Lamarche et al. (2020) stated that the effects of depression will cause stress that ultimately affects the individual's wellbeing and organizational performance. The other effects of not feeling happy while doing their job are that employees will easily feel sad, anxious, empty, desperate, feeling invaluable, become upset and anxious. In addition, it is worrying if employees may lose interest to work, unable to concentrate, lose appetite and attempt suicide (Aziz, 2014). The findings from Registrar's study at one of the universities in South Malaysia found that the frequency of taking sick leave, high medical expenses, often be late to office, skipping work, schizophrenia, doing part-time job, and taking excessive annual leave are seen among the symptoms that the university staff is dealing with stress problems at workplace.

The cause of stress in organizations can be seen from various angles including excessive workload, poor employee roles, inefficient organizational management, auto efficiency leadership, poor communication system, challenges while working and upgrading of employee life (Yurtkorub, 2013). The physical environment of the non-ergonomic work and inconsistent workload can worsen stress problems in the workplace (Zafir \& Fazilah, 2010). The working station environment has a very close relationship with employee stress level as employees will spend the whole work time at their workstation.

Tajudeen (2004) and Cooper \& Marshall (1978) in their theories have stated that stress at work caused from environmental factors such as relationships, work intrinsic, organizational structure and climate. The relationship component covers the aspect of relationship with the top employees with co-workers. The structure and climate factors of the organization include the lack of engagement, poor communication and no sense of belonging. This emphasis will pressure the parties if they fail to control the stress. The prolonged tension will lead to physical and mental health problems. Physical health problems are such as rising pulse rate, high blood pressure, high cholesterol levels and heart disease. Mental health problems include less motivation, emotionally depressed, no job satisfaction and lack of aspiration. 
Organizational environment greatly influences employee stress levels. Factors such as ventilation system, lighting, overcrowded working space, sound system and extreme temperatures can affect the stress levels of workers (Sunarsi, 2020)(Bao et al, 2009). In addition, the organizational structure and climate that limits the autonomy of workers also cause employees to feel stressed. In this context, employees feel that they have no control over their duties besides feeling that the organization does not trust them to perform the jobs. As a result, employees slowdown in doing the same task and feel that there is no challenge in doing a new task, feel pain and humility and loss of identity as an employee which ultimately contribute to the dissatisfaction of work (Haryati \& Rahardjo, 2013).

Akinmayowa \& Kadiri (2016) found that academic workload, student-related issues, research and career development, interpersonal relationship, administrative-related issues as factors that contribute significantly to the level of stress experienced by academic staff. Yusoff et al. (2013) in his study identified the following source of stress among university lecturers as such as lots of works load, inadequate ventilated office, noisy environment, multiple university problems, inadequate lecture halls, keeping pace with institutional demands, role expectation, emotional demand inter-personal relationship value, and belief system(Yusoff, R.B, \& Khan, A. \& Azam, 2013). Meanwhile, Ahmed et al. (2014) affirmed that work load, role conflict and inadequate monetary rewards are the main causes of stress among employees in Higher Education Sector, which reduce their work performance. Masuku \& Muchemwa (2015) stated that present day workplace has increased the levels of work-related stress, which contribute to various problems both for the individual employee experiencing stress and for the organization for which one works.

An organization includes higher education such as the university (Chong et al, 2020), polytechnic (Ramlee et al., 2020) and community college (Diana, 2011) which also face the same situations on stress issues at the work place. These include, work overload, time constraint, lack of promotion opportunities, inadequate recognition, inadequate salary, changing job role, inadequate management or participation in management, inadequate resources and funding, and student interaction (Gillespie et al., 2001)(Darabi et al. 2017). Other sources of stress, such as work-related technology (Schuldt \& Totten, 2008)(Isa et al., 2019) years of experience, job-type category (Dua, 1994), workload (Isa et al., 2019), and work environment (Zafir \& Fazilah, 2010) been highlighted in a few studies.

\section{Methodology}

This study was conducted in Malaysian Public Universities and involved 609 respondents who were randomly selected using the table of Morgan \& Krejcie (1970). The 609 is the approximate recommendation of sample size based on the 31,740 academician population in Malaysian Public Universities with 98\% confidence level ( $\alpha$ ) (Quick Fact, 2018). The questionnaire were contributed online among the academician of Malaysian Public Universities email address. The development of the items was done based on previous quantitative and qualitative research. Pretest and pilot test have been applied in the development of the questionnaire. Based on the pretest and pilot test results, some amendments were made on the final set of questionnaire to be used in this research (Alavi, Isa, \& Palpanadan, 2020).

The questionnaire was divided into three sections where section A measured the respondents' demographic information, section B measured the level stress of lecturers' and section C listed the ranking of major prevalence causes that contributed to lecturers' stress. There were 33 items which consisted of three main constructs, including the organization (referring to university), social and individual. Each construct contained three to four sub constructs and there were three items in each sub constructs. Four points Likert Scale has been used in this survey: 1- Strongly Disagree, 2 - Disagree, 3 - Agree and 4 - Strongly Agree. Table 1 shows the details of the construct items. The data were analysed descriptively using the Statistical Package for Social Science (SPSS) program version 20.

Frequencies and descriptive statistics were used to analyze the data. Inferential statistical was used to accept or reject the alternate hypothesis. If the statistical analysis shows that the significance level is below the cut-off value (such as either 0.05 or 0.01 ), the null hypothesis could be rejected or the alternative hypothesis could be accepted. The reliability test showed that the alpha value for all the variables of this study was 0.907 which according to Sekaran (2003), if the reliability test value was $>0.7$, it was acceptable and reliable. The score mean for each variable is divided into three categories which are low, moderate and high as shown in Table 1.

Table 1. Mean Score of Variable

\begin{tabular}{ll}
\hline Score range & Mean value \\
\hline $1.00-2.33$ & Low \\
$2.34-3.66$ & Moderate \\
$3.67-5.00$ & High \\
\hline
\end{tabular}




\subsection{Findings and Discussion}

\subsubsection{Section A: Respondents' Demographic}

Figure 1 Table 2 shows the 609 lecturers' responses from Malaysian Public University who were selected randomly to participate in this study. A total of 342 out of 609 respondents were females and the rest were males $(n=267)$. Based on the analysis, the majority of the respondents were Malays $(n=520)$ followed by Others $(n=49)$, Chinese $(n=34)$ and just a very small numbers of Indians $(n=6)$. Most of the respondents were Muslim $(n=550)$ and the rest of them were Christians $(n=35)$, Buddhists $(n=23)$ and Hindus $(n=1)$. The data showed a total of 276 respondents had served for 11-20 years at the university, 189 of them had served less than 10 years and 114 of them had served between $21-30$ years. Only 30 respondents had served for more than 31 years. From the data given, it could be seen that most of the respondents were in the category of young lecturer in the university and just a small number of them were seniors. There were three categories of universities involved in this research and most of the respondents were from focus university $(n=242)$, followed by comprehensive university $(n=188)$ and research university $(n=179)$. Each university has a different focus and niche area but the basic requirement as a lecturer was still same. According to Faraji (2019), the demographic factor such as gender, age, service period and marriage status of respondents had caused different levels of stress.

Table 2. Demographic Factor Analysis among Respondents

\begin{tabular}{|c|c|c|}
\hline Category & Frequency & Percentage (100\%) \\
\hline \multicolumn{3}{|l|}{ Gender } \\
\hline Male & 267 & 43.8 \\
\hline Female & 342 & 56.2 \\
\hline Total & 609 & 100 \\
\hline \multicolumn{3}{|l|}{ Ethnic } \\
\hline Malay & 520 & 85.4 \\
\hline Chinese & 34 & 5.6 \\
\hline Others & 49 & 8.0 \\
\hline Indian & 6 & 1.0 \\
\hline Total & 609 & 100 \\
\hline \multicolumn{3}{|l|}{ Religion } \\
\hline Muslim & 550 & 90.3 \\
\hline Buddha & 23 & 3.8 \\
\hline Christian & 35 & 5.7 \\
\hline Hindu & 1 & 0.2 \\
\hline Total & 609 & 100 \\
\hline \multicolumn{3}{|l|}{ Service Period } \\
\hline$<-10$ years & 189 & 31 \\
\hline $11-20$ years & 276 & 45.3 \\
\hline $21-30$ years & 114 & 18.7 \\
\hline $30>$ year & 30 & 5 \\
\hline Total & 609 & 100 \\
\hline \multicolumn{3}{|l|}{ Categories university } \\
\hline Focus university & 242 & 40 \\
\hline Coprehensive university & 188 & 30.7 \\
\hline Research University & 179 & 29.3 \\
\hline Total & 609 & 100 \\
\hline
\end{tabular}




\subsubsection{Section B: The Stress Level of Lecturers}

Table 3 shows that the stress level of Malaysian lecturers was at low level with mean value 2.25. This finding revealed that Malaysian public universities lecturers were not stressed at work place. Based on the three variables tested, the data showed that social factor had a high level of stress with mean value 2.230 , followed by university factor (mean $=$ 2.146) and individual factor (mean $=2.043$ ). Even with low stress levels, lecturers seemed to become easily stressed due to the work load and work activities (mean $=2.8823$ ) followed by work environment and work station with mean value 2.8209. According to Zafir \& Fazilah (2010), ergonomic work station has a significant influence to happiness and stress level of employees. However, job specification only contributes a little effect to the stress of lecturers with the mean value of 1.973 . Meanwhile, leadership (mean $=2.256)$ and income and compensation (mean $=2.042)$ only have a small amount of contribution of stress to the lecturers.

Social factor had been identified as a main factor that contributed to the stress of lecturers (mean $=2.230$ ). As a part of work activities as lecturers, the element of networking had been found to have an effect towards stress on lecturers with mean value 2.493. However, friendship and social relation only contributed low level of stress on lecturers with mean value 2.030. This is probably due to the element of networking which was more on work relation based meanwhile; friendship and social relation were more organization based.

Individual factor had been found to have a low effect towards lecturers' stress with mean value 2.043. Health and personal showed a high influence towards lecturers' stress (mean $=2.287)$ compared to religion $($ mean $=1.910)$ and financial (mean $=1.932)$. This result showed that lecturers who had a good financial and religion practices had less tendency to be stressed.

Table 3. Stress level of Malaysian Lecturer

\begin{tabular}{lll}
\hline Item & mean & $\begin{array}{l}\text { Std. } \\
\text { deviation }\end{array}$ \\
\hline (A) University & 2.8823 & .44377 \\
Work load and work activities & 2.8209 & .75451 \\
Work environment and work station & 2.0423 & .78479 \\
Income and compensation & 2.2568 & .79727 \\
leadership & 1.9733 & .73203 \\
Job specification & $\mathbf{2 . 1 4 6}$ & \\
& & \\
(B) Social & 2.1693 & .71293 \\
Family support & 2.0307 & .76914 \\
Friendship/social relation & 2.4939 & .82751 \\
networking & $\mathbf{2 . 2 3 0}$ & \\
I Individual & & \\
Religion & 1.9107 & .67629 \\
Financial & 1.9322 & .64710 \\
Health and Personal & 2.2875 & .66232 \\
Total mean (A+b+C) & $\mathbf{2 . 0 4 3}$ & \\
\hline
\end{tabular}

Based on Table 4, all three measured factors had a relationship with lecturers' stress. It showed that university factor, social factor and individual factor contributed to lecturers' stress even the previous findings showed that lecturers' level of stress was at the low level. This finding indirectly indicated that each factor contributed to lecturers' stress at a different significant level.

Table 4. Correlation between stress factors

\begin{tabular}{lllll}
\hline Respondent & Correlation & university & social & individual \\
\hline \multirow{3}{*}{ lecturer } & Pearson Correlation & $.905^{* *}$ & $.907^{* *}$ & $.792^{* *}$ \\
& Sig. (2-tailed) & .000 & .000 & .000 \\
& $\mathrm{~N}$ & 609 & 609 & 609
\end{tabular}

**. Correlation is significant at the 0.01 level (2-tailed). 


\subsection{Ranking of Major Prevalence Causes towards Lecturers'Stress}

Table 5 shows the ranking of major prevalence cause towards lecturers' stress level in relation to university factor. Based on the analysis, the key prevalence factors that contributed the most towards stress among lecturers in Malaysia were too much ad-hoc task given to me (mean $=3.38)$, my work station is tedious (mean $=2.47)$, my work station space has no adequate facilities (mean $=2.89)$, job specification make my emotion easily distracted $($ mean $=2.78)$ and too many university Key Performances Indicator need to be accomplished then cause my career planning to be interrupted (mean $=2.50)$. Too much ad-hoc tasks given to me was ranked the first significant factors followed by my work station is tedious as the second prevalence, my work station space has no adequate facilities as the third prevalence, job specification make my emotion easily distracted as a fourth prevalence and too many university Key Performances Indicator need to be accomplished then cause my career planning to be interrupted as the fifth prevalence could be seen as major factors that account for stress among respondents. The most stressful aspect arised from the workload and work environment which was supported by Danku et al. (2017), that work load was the major causes or sources of stress among the lecturers. Meanwhile, Zafir \& Fazilah (2010) and Isa et al. (2019) from his study found that the ergonomic work station have a significant relation to the happiness of employee at the work place.

However, the findings showed that looking research opportunity with stakeholder (mean $=1.68$ ) and lecturer prefer to do community service than publication (mean $=2.00$ ) did not really affect the stress levels of the respondents. This findings was similar to a study was done by Ismail \& Arma (2016) which found that sourcing for research grant has a low contribution towards stress with mean value 1.90. Salary increment (mean $=1.98$ ) and not comprehensive compensation package (mean $=2.00$ ) were defined as a low prevalence to the stress of lecturers as stated by Danku et al. (2017) who indicated that delay or irregularity in payment of salary and inadequate monetary reward were identified as major causes of stress among lecturers.

Table 5. Ranking of prevalence cause towards lecturers' stress level based on university factor

\begin{tabular}{|c|c|c|}
\hline University Factor & mean & ranking \\
\hline \multicolumn{3}{|l|}{ Workload and job activities } \\
\hline 1. Job specification makes my emotion easily distracted. & 2.78 & 4 \\
\hline Too much ad-hoc task given to me & 3.38 & 1 \\
\hline $\begin{array}{l}\text { 3. Too many university Key Performances Indicator need to be } \\
\text { accomplished then cause my career planning to be interrupted }\end{array}$ & 2.50 & 5 \\
\hline \multicolumn{3}{|l|}{ Work environment and work station } \\
\hline 1. My work station space has no adequate facilities. & 2.89 & 3 \\
\hline My work station is tedious & 3.07 & 2 \\
\hline 3. I always had to borrow work equipment from other partners & 2.47 & 6 \\
\hline \multicolumn{3}{|l|}{ Salary and Compensation } \\
\hline 1. The salary received is not enough for the living. & 2.16 & 11 \\
\hline I disagree with the salary increment system. & 1.98 & 13 \\
\hline 3. The compensation package provided is not comprehensive & 2.00 & 12 \\
\hline \multicolumn{3}{|l|}{ Leadership } \\
\hline 1. My leader is an autocratic & 2.18 & 10 \\
\hline Head of department have no stand in decision making & 2.30 & 7 \\
\hline $\begin{array}{l}\text { 3. Head of department frequently use roughly speaking with } \\
\text { subordinate }\end{array}$ & 2.29 & 8 \\
\hline \multicolumn{3}{|l|}{ Job specification } \\
\hline $\begin{array}{l}\text { 1. Marking an assignment of the student is the last part on my priority } \\
\text { list. }\end{array}$ & 2.24 & 9 \\
\hline $\begin{array}{l}\text { 2. I am feeling depressed when asked for a research opportunity with } \\
\text { the stakeholder. }\end{array}$ & 1.68 & 14 \\
\hline I prefer in community service activities instead of writing a book. & 2.00 & 12 \\
\hline
\end{tabular}


Based on the summary result in Table 6, it can be seen that I don't like to deal with other friends who do not agree with me $($ Mean $=2.76)$, very hard to find friends from other universities to carry out work related matters $($ mean $=2.59)$, work load at home ruined my focus while at work place (mean $=2.47)$, family did not understand my commitment at work (mean $=2.40)$ and I've seen as a threat to other co workers $($ mean $=2.19)$ were major prevalence of stress for lecturers. It showed that the elements of networking and interaction with others had caused some stress to lecturers as stated by Ismail \& Arma (2016) who also stated that linkage to other professionals in research discipline contributed to lecturers' stress. However, colleagues do not support while performing duties $($ mean $=1.88)$ had been identified as a factor that did not really affect the lecturer and this study was in contrast with Archibong et al. (2010) and Espedido (2020) who found that stress was closely linked with the situation if the academic staff interacted with peers of the same professional field. In addition, family matters also found to affect the lecturers' stress which were work load at home ruined my focus while at work place (mean $=2.47$ ) and family did not understand my commitment at work (mean =2.40). In line with Aryee et al. (2013) and Karapinar et al. (2019), this study found that family supportive environment had an impact on work behavior.

Table 6. Ranking of prevalence cause towards lecturers' stress level based on social factor

\begin{tabular}{|c|c|c|c|}
\hline \multicolumn{2}{|c|}{ Social Factor } & mean & ranking \\
\hline \multicolumn{4}{|c|}{ Family } \\
\hline 1. & Family did not understand my commitment at work. & 2.40 & 4 \\
\hline 2. & Work load at home ruined my focus while at work place. & 2.47 & 3 \\
\hline 3. & $\begin{array}{l}\text { Not enough rest at home make me depressed while in } \\
\text { the workplace. }\end{array}$ & 1.73 & 9 \\
\hline \multicolumn{4}{|c|}{ Friendship and social interaction } \\
\hline 1. & Colleagues do not support while performing duties & 1.88 & 8 \\
\hline 2. & I've seen as a threat to other co workers & 2.19 & 5 \\
\hline 3. & Bias culture has been practice in the organizations & 2.06 & 7 \\
\hline \multicolumn{4}{|c|}{ Networking } \\
\hline 1. & $\begin{array}{l}\text { Interacting with other parties using social media has a tendency to pose } \\
\text { misinterpretation. }\end{array}$ & 2.12 & 6 \\
\hline 2. & $\begin{array}{l}\text { I am very hard to find friends from other universities to carry out work } \\
\text { related matters. }\end{array}$ & 2.59 & 2 \\
\hline 3. & I don't like to deal with other friends who do not agree with me. & 2.76 & 1 \\
\hline
\end{tabular}

Table 7 presents the prevalence cause of lecturers' stress based on individual factor. As it can be seen that I am not sure when making a decision at the workplace (mean $=3.20)$, I had to use a credit card for an out of cash every month (mean $=2.23)$, more friends gossip from discussing things related to work $($ mean $=2.22)$, I am easily influenced by more dominant people $($ mean $=2.08)$ and $I$ feel threatened when another friend is more successful than me $(\mathrm{mean}=$ 2.05) were founded as major prevalence that contributed to lecturers' stress. This result indirectly showed that self esteem among lecturers plays an important role in the way they handle their stress. According to Isa \& Palpanadan (2020), many lecturers preferred to conduct their own work as academicians with the belief that everyone had the beauty of their own journey which had been planned by God.

Table 7. Ranking of prevalence cause towards lecturers' stress level based on individual factor

\begin{tabular}{lll} 
Individual Factor & mean & ranking \\
\hline Religion & & \\
1. I feel threatened when another friend is more successful than me & 2.05 & 5 \\
2. More friends gossip from discussing things related to work & 2.22 & 3 \\
3. I see another friend's life more perfect than my life & 1.48 & 9 \\
Financial & & \\
1. I had to use a credit card for an out of cash every month. & 2.23 & 2 \\
2. I made a part-time job to pay various installment debts every month. & 1.92 & 6 \\
3. My emotions are often interrupted when they are thinking about debt. & 1.67 & 7 \\
Health and personal & & \\
1. I will feel guilty if it is not able to complete the task according to the time & 1.66 & 8 \\
2. I am easily influenced by people more dominant. & 2.08 & 4 \\
3. I am not sure when making a decision at the workplace. & 3.20 & 1
\end{tabular}




\section{Conclusion}

This research clearly showed that the stress existed among Malaysian lecturers even at low level and there were three main factors including university factor, social factor and individual factor that had significant relationships to lecturers' stress. Work load, work environment, networking, health and financial were found to be the major prevalence to lecturers' stress. However, salary and compensation, friendship and social interaction and religion were found to have less impact towards lecturers' stress. Nonetheless, in other point of view, most of the Malaysian lecturers were found to be under control in managing their emotion and work life. The findings of this study could be used to identify proper intervention program for stress coping strategies involving the management of the university and also the lecturers.

\section{Acknowledgment}

The authors would like to thank The Ministry of Higher Education (MOHE) for supporting this research through Fundamental Research Grant Scheme (FRGS/1/2019/SS03/UTHM/02/4) with Vot: K226 and also Universiti Tun Hussein Onn Malaysia (UTHM). We would like to show our gratitude to the respondents for their full support for this research.

\section{References}

Ahmed, R. R., Warraich, U. A., Khoso, I., \& Ahmad, N. (2014). Impact of stress on job performance: an empirical study of the employees of private sector universities of Karachi. Global Management Journal for Academic and Corporate Studies, 4(2), 104-108.

Akinmayowa, J. T., \& Kadiri, P. A. (2016). Stress among academic staff in a nigerian university. Covenant Journal of Business and Social Sciences, 6(1).

Alavi, K., Isa, K., \& Palpanadan, S. T. (2020). Application of Rasch Model on Resilience in Higher Education: An Examination of Validity and Reliability of Malaysian Academician Happiness Index. International Journal of Higher Education, 9(4), 261. https://doi.org/10.5430/ijhe.v9n4p261

Archibong, I. A., Bassey, A. O., \& Effiom, D. O. (2010). Occupational stress sources among university academic staff. European Journal of Educational Studies, 2(3), 217-225. https://doi.org/10.4314/afrrev.v3i2.43639

Aryee, S., Chu, C. W. L., Kim, T.-Y., \& Ryu, S. (2013). Family-supportive work environment and employee work behaviors: An investigation of mediating mechanisms. Journal of Management, 39(3), 792-813. https://doi.org/10.1177/0149206311435103

Aziz, A. R. A. (2014). Happiness Sustainable among Lecturers at the Malaysian Research University. Universiti Teknologi Malaysia. Skudai. https://doi.org/10.1016/j.sbspro.2014.01.918

Bao, S., Spielholz, P., Howard, N., \& Silverstein, B. (2009). Force measurement in field ergonomics research and application. International Journal of Industrial Ergonomics, 39(2), 333-340. https://doi.org/10.1016/j.ergon.2008.03.005

Bianchi, R., Schonfeld, I. S., \& Laurent, E. (2019). Burnout: Moving beyond the status quo. International journal of stress management, 26(1), 36. https://doi.org/10.1037/str0000088

Chong, S. C., Falahat, M., \& Lee, Y. S. (2020). Emotional Intelligence and Job Performance of Academicians in Malaysia. International Journal of Higher Education, 9(1), 69-80. https://doi.org/10.5430/ijhe.v9n1p69

Cooper, C. L., \& Marshall, J. (1978). Understanding executive stress. Springer. https://doi.org/10.1007/978-1-349-03030-9

Espedido, A., Searle, B. J., \& Griffin, B. (2020). Peers, proactivity, and problem-solving: A multilevel study of team impacts on stress appraisals of problem-solving demands. Work \& Stress, 34(3), 219-237. https://doi.org/10.1080/02678373.2019.1579767

Danku, L, S., Dzomeku, V, M., T., D. C., \& Adade, T, C. (2017). Stress Among Private University Lecturers in Ghana: Causes And Coping Strategies. 259(January), 95-101.

Darabi, M., Macaskill, A., \& Reidy, L. (2017). A qualitative study of the UK academic role: positive features, negative aspects and associated stressors in a mainly teaching-focused university. Journal of Further and Higher Education, 41(4), 566-580. https://doi.org/10.1080/0309877X.2016.1159287

Deepti, B. and Hemant, T. (2018). A Study of Causes of Stress and Stress Management among Youth. International Journal of Management \& Social Science. 11(3), 108-117. http://doi.org/10.21013/jmss.v11.n3.p1 
Diana, N. S. (2011). Tahap Stress di Kalangan Pensyarah Kolej Komuniti di Sekitar Negeri Johor. Universiti Teknologi Malaysia, Skudai.

Dua, J. K. (1994). Job stressors and their effects on physical health, emotional health and job satisfaction in a university. Journal of Educational Administration. https://doi.org/10.1108/09578239410051853

Faraji, A., Karimi, M., Azizi, S. M., Janatolmakan, M., \& Khatony, A. (2019). Occupational stress and its related demographic factors among Iranian CCU nurses: a cross-sectional study. BMC research notes, 12(1), 634. https://doi.org/10.1186/s13104-019-4674-5

Fowler, N. (2018). The Power of Resilience: How Stewards in Palliative Healthcare Settings Can Leverage Resilience to Combat Staff Burnout. Leadership in Healthcare and Public Health.

Gillespie, N. A., Walsh, M., Winefield, A. H., Dua, J., \& Stough, C. (2001). Occupational stress in universities: Staff perceptions of the causes, consequences and moderators of stress. Work \& Stress, 15(1), 53-72. https://doi.org/10.1080/02678370117944

Haryati, R., \& Rahardjo, S. N. (2013). Pengaruh Corporate social responsibility, Kinerja Lingkungan Dan Struktur Corporate Governance Terhadap Kinerja Keuangan Perusahaan Yang Terdaftar Di Bursa Efek Indonesia. [Influence of Corporate social responsibility, Environmental Performance and Corpor. Fakultas Ekonomika dan Bisnis.

Hoel, H., Cooper, C. L., \& Einarsen, S. V. (2020). Organisational effects of workplace bullying. Bullying and Harassment in the Workplace: Theory, Research and Practice, 209. https://doi.org/10.1201/9780429462528-7

Isa, K., Jam, N. A. M., Muda, W. H. N. W., \& Kadir@Shah, H. (2019). Crucial Personal Factors Leading to Stress in University. International Journal of Engineering and Advanced Technology, 9(1), 4305-4309. https://doi.org/10.35940/ijeat.A1268.109119

Isa, K., \& Palpanadan, S. T. (2020). A Preliminary Study of Stress in Higher Education and Contributing Factors to Lecturers. International Journal of Advanced Science and Technology, 29(5), 12047-12057. https://doi.org/10.1002/j.1556-6978.2010.tb00107.x

Isa, K., Damin, Z. A., Jaes, L., Latiff, A. A., Abdul, A. H., Rahman, A. K., ... \& Tenah, S. S. (2019). Domains That Lead To Happiness At Workplace. International Journal of Engineering and Advanced Technology, 8(5C). https://doi.org/10.35940/ijeat.E1101.0585C19

Ismail, N. H., \& Arma. (2016). Occupational stress and its associated factors among academician in a research university, Malaysia. Malaysian Journal of Public Health Medicine, 16(1), 81-91.

Karapinar, P. B., Camgoz, S. M., \& Ekmekci, O. T. (2019). Employee Wellbeing, Workaholism, Work-Family Conflict and Instrumental Spousal Support: A Moderated Mediation Model. Journal of Happiness Studies, 1-21. https://doi.org/10.1007/s10902-019-00191-x

Masuku, S., \& Muchemwa, S. (2015). Occupational stress among university lecturers: A case of Zimbabwe. US-China Education Review, 5(4), 258-266. https://doi.org/10.17265/2161-623X/2015.04.003

Morgan, \& Krejcie. (1970). Sample size determination using Krejcie and Morgan table. Educational and Psychological Measurement, 30, 607-610. https://doi.org/10.1177/001316447003000308

Okeke, M. N., Echo, O., \& Oboreh, J. C. (2016). Effects of stress on employee productivity. International Journal of Accounting Research, 42(3495), 1-12.

Ormrod, J. E. (2013). Educational psychology: Pearson new international edition: Developing learners. Pearson Higher Ed.

Parent-Lamarche, A., Marchand, A., \& Saade, S. (2020). Does Depression Mediate the Effect of Work Organization Conditions on Job Performance?. Journal of Occupational and Environmental Medicine, 62(4), 296-302. https://doi.org/10.1097/JOM.0000000000001822

Quick Facts (2018). Malaysia Educational Statistics. Education Data Sector, Education Planning and Research Division, Ministry of Education Malaysia.

Rahim, N. A., \& Yatim, N. M. (2017). Hubungan Kepuasan Kerja Terhadap Prestasi Kerja Dalam Kalangan Pensyarah: Satu Kajian Di Kolej Komuniti Bukit Beruang Melaka.

Ramlee, M. F. M., \& Bakar, A. Y. A. (2020). Stress and Job Satisfaction Among Polytechnic Lecturers in Malaysia: A Need Analysis Study. Bisma The Journal of Counseling, 4(1), 1-6. http://doi.org/10.23887/bisma.v4i1.24708 
Schuldt, B., \& Totten, J. (2008). An exploratory study: Business faculty and the faculty stress index. Proceedings of the Allied Academies, 13(2), 128-133.

Sekaran, U. (2003). Towards a guide for novice research on research methodology: Review and proposed methods. Journal of Cases of Information Technology, 8(4), 24-35.

Sunarsi, D. (2020). The Analysis of The Work Environmental and Organizational Cultural Impact on The Performance and Implication of The Work Satisfaction. Jurnal Ilmiah Ilmu Administrasi Publik, 9(2), 237-246. https://doi.org/10.26858/jiap.v9i2.11761

Sweeny, K., Howell, J. L., \& Kwan, V. W. (2020). Losing control: Comparing the role of personality during two types of stressful life experiences. Personality and Individual Differences, 156, 10977. https://doi.org/10.1016/j.paid.2019.109771

Tajudeen, A. B. A. (2004). Kepuasan kerja dan tekanan yang dihadapi oleh guru sekolah menengah. (Doctoral dissertation, Universiti Putra Malaysia).

Yurtkorub, S. (2013). Job stress and job performance among employees in public sector in Istanbul: examining the moderating role of emotional intelligence. Procedia-Social and Behavioral Sciences, 75, 518-524. https://doi.org/10.1016/j.sbspro.2013.04.056

Yusoff, R.B, \& Khan, A. \& Azam, K. (2013). Job Stress, Performance and Emotional Intelligent in Academia. 3(6), 1-8. https://doi.org/10.1.1.1058.8813

Zafir, M. M., \& Fazilah, M. H. (2010). Stress at the Work place: How the Ergonomic Factors Minimize it? The 5th National Human Resource Management Conference 2010, 642-657. Universiti Utara Malaysia. Sintok. https://doi.org/10.1080/00140130400029282. 